\title{
Differential Effects of Ruminant and Industrial 18-Carbon trans-Monounsaturated Fatty Acids (trans Vaccenic and Elaidic) on the Inflammatory Responses of an Endothelial Cell Line
}

\author{
Carina A. Valenzuela ${ }^{1,2, * \mathbb{D}}$, Ella J. Baker ${ }^{1}$, Camila O. De Souza ${ }^{1,3}$, Elizabeth A. Miles ${ }^{1} \mathbb{D}$ and Philip C. Calder ${ }^{1,4} \mathbb{C}$ \\ 1 School of Human Development and Health, Faculty of Medicine, University of Southampton, \\ Southampton SO16 6YD, UK; E.Baker@soton.ac.uk (E.J.B.); \\ Camila.oliveiradesouza@utsouthwestern.edu (C.O.D.S.); e.a.miles@soton.ac.uk (E.A.M.); \\ pcc@soton.ac.uk (P.C.C.) \\ 2 School of Nutrition, Faculty of Pharmacy, University of Valparaíso, Playa Ancha, Valparaíso 2360102, Chile \\ 3 Department of Cell and Developmental Biology, Institute of Biomedical Sciences, University of São Paulo, \\ São Paulo CEP 05508-000, SP, Brazil \\ 4 NIHR Southampton Biomedical Research Centre, University Hospital Southampton NHS Foundation Trust \\ and University of Southampton, Southampton SO16 6YD, UK \\ * Correspondence: carina.valenzuela@uv.cl
}

Citation: Valenzuela, C.A.; Baker, E.J.; De Souza, C.O.; Miles, E.A.; Calder, P.C. Differential Effects of Ruminant and Industrial 18-Carbon trans-Monounsaturated Fatty Acids (trans Vaccenic and Elaidic) on the Inflammatory Responses of an Endothelial Cell Line. Molecules 2021, 26, 5834. https://doi.org/10.3390/ molecules26195834

Academic Editors: Raluca Maria Pop, Ada Popolo and Stefan Cristian Vesa

Received: 25 August 2021

Accepted: 23 September 2021

Published: 26 September 2021

Publisher's Note: MDPI stays neutral with regard to jurisdictional claims in published maps and institutional affiliations.

Copyright: (c) 2021 by the authors Licensee MDPI, Basel, Switzerland. This article is an open access article distributed under the terms and conditions of the Creative Commons Attribution (CC BY) license (https:/ / creativecommons.org/licenses/by/ $4.0 /)$.
Abstract: Endothelial dysfunction and inflammation are recognised factors in the development of atherosclerosis. Evidence suggests that intake of industrial trans fatty acids (TFAs) promotes endothelial dysfunction, while ruminant TFAs may have the opposite effect. The aim of this study was to compare the effects of elaidic acid (EA (18:1n-9t); an industrially produced TFA) and trans vaccenic acid (TVA (18:1n-7t); a natural TFA found in ruminant milk and meat) on inflammatory responses of endothelial cells (ECs). ECs (EA.hy926 cells) were cultured under standard conditions and exposed to TFAs ( 1 to $50 \mu \mathrm{M}$ ) for $48 \mathrm{~h}$. Then, the cells were cultured for a further 6 or $24 \mathrm{~h}$ with tumour necrosis factor alpha (TNF- $\alpha, 1 \mathrm{ng} / \mathrm{mL}$ ) as an inflammatory stimulant. ECs remained viable after treatments. TFAs were incorporated into ECs in a dose-dependent manner. Preincubation with EA $(50 \mu \mathrm{M})$ increased production of MCP-1, RANTES, and IL- 8 in response to TNF- $\alpha$, while preincubation with TVA $(1 \mu \mathrm{M})$ decreased production of ICAM- 1 and RANTES in response to TNF- $\alpha$. Preincubation with EA $(50 \mu \mathrm{M})$ upregulated toll-like receptor 4 and cyclooxygenase 2 gene expression in response to TNF- $\alpha$. In contrast, preincubation with TVA $(1 \mu \mathrm{M})$ downregulated TNF- $\alpha$ induced nuclear factor kappa B subunit 1 gene expression. Preincubation of ECs with EA (50 $\mu \mathrm{M})$ increased THP-1 monocyte adhesion. In contrast, preincubation of ECs with TVA $(1 \mu \mathrm{M})$ reduced THP-1 monocyte adhesion, while preincubation of ECs with TVA $(50 \mu \mathrm{M})$ decreased the level of surface expression of ICAM-1 seen following TNF- $\alpha$ stimulation. The results suggest that TVA has some anti-inflammatory properties, while EA enhances the response to an inflammatory stimulus. These findings suggest differential effects induced by the TFAs tested, fitting with the idea that industrial TFAs and ruminant TFAs can have different and perhaps opposing biological actions in an inflammatory context.

Keywords: trans fatty acids; elaidic acid; trans vaccenic acid; inflammation; atherosclerosis

\section{Introduction}

Coronary heart disease (CHD) and stroke are still the leading causes of death globally [1], and atherosclerosis has a key role in their pathogenesis. Atherosclerosis is a lipoprotein-driven disease that leads to plaque formation at focal areas in the arterial blood vessels through intimal inflammation, necrosis, fibrosis, and calcification [2]. Low-grade chronic inflammation is a feature of obesity and has been related to insulin resistance and atherosclerosis $[3,4]$. Endothelial dysfunction is a pro-inflammatory state characterised by chronic activation of the endothelium, which leads to atherosclerosis and cardiovascular 
disease (CVD). The vascular endothelium plays a key role in maintaining vascular homeostasis by regulating vascular tone and permeability, thrombosis, haemostasis, and other inflammatory responses $[5,6]$.

High intake of trans fatty acids (TFAs) is associated with an increased risk of CVD [7-10], which explains the recommendation that these fatty acids (FAs) should contribute $<1 \%$ of daily energy intake [11]. However, there are two different dietary sources of TFAs: the industrially produced TFAs (iTFAs) and the naturally occurring or ruminant TFAs (rTFAs). iTFAs are produced industrially by partial hydrogenation of vegetable oils and are found in ultra-processed or ready-to-eat foods such as fried foods, fast foods, pastries, shortenings, cake mixes, and many frozen meals and packaged foods [12]. In contrast, rTFAs are generated by biohydrogenation of unsaturated FAs in the rumen of grass grazing sheep and cattle and other ruminants by bacterial isomerases, and therefore they are found in the milk, dairy products, and meat of these ruminant animals [12]. Given that partially hydrogenated vegetable oils can contain between 30 and $50 \%$ of iTFAs, mainly elaidic acid (EA; 18:1n-9t), while dairy and ruminant products only have between 2 and $6 \%$ of rTFAs (mostly trans vaccenic acid, (TVA; $18: 1 \mathrm{n}-7 \mathrm{t}$ )), quantitatively the main dietary source of TFAs is usually partially hydrogenated vegetable oils [13].

The evidence from observational studies suggests that higher CVD risk is related to consumption of iTFAs rather than rTFAs, which can be explained, at least in part, by their differential effects on lipoproteins such as low-density lipoprotein (LDL) and high-density lipoprotein (HDL) cholesterol, as well as inflammatory mechanisms [14-16]. However, it is not clear how specific TFA isomers differ in their biological activity and mechanisms of action with regard to inflammation.

There are not many studies comparing the effects of TFAs of industrial and ruminant origin in models of endothelial inflammation. In vitro studies, both under basal conditions and after exposure to inflammatory stimuli, usually show that iTFAs have proinflammatory effects [17-19], while rTFAs have null or the opposite effects to iTFAs [17,20], although the evidence is not always consistent [21,22]. It is difficult to compare the studies testing the effects of TFAs of different origins on inflammatory processes in endothelial cells (ECs), and in other cells, given the methodological differences between them, particularly the use of high concentrations of these TFAs, which may be considered unphysiological when compared with TFA levels reported in human blood [13].

In view of the need for greater knowledge regarding the possible differential effects of TFAs on inflammation, the aim of this study was to compare the inflammatory responses in cultured EA.hy926 ECs exposed to the most common 18-carbon TFAs of both industrial and ruminant origin (EA and TVA) and their cis isomers oleic (OA; 18:1n-9) and cis vaccenic acid (CVA; 18:1n-7), after stimulation with the inflammatory cytokine tumour necrosis factor (TNF- $\alpha$ ). The objective of this study was to gain insight into the mechanisms through which TFAs in general, and 18-carbon iTFAs and rTFAs in particular, affect inflammation and the functioning of human ECs, which is important in relation to development of atherosclerosis and the consequent risk for CVD.

\section{Results}

\subsection{Viability of EA.hy926 Cells Incubated with TNF- $\alpha$ and FAs}

Neither TNF- $\alpha(1 \mathrm{ng} / \mathrm{mL}$ for $24 \mathrm{~h})$ nor any of the four FAs tested at concentrations of 1, 10, and $50 \mu \mathrm{M}$ affected the viability of EA.hy926 cells, as assessed using the 3-(4,5dimethylthiazol-2-yl)-2,5-diphenyltetrazolium bromide (MTT) assay (Figure 1). However, at a concentration of $100 \mu \mathrm{M}$, both EA and TVA reduced viability by an average of $20 \%$. Therefore, further experiments did not use FAs at concentrations above $50 \mu \mathrm{M}$. The effects of OA and CVA on EC viability at a concentration of $100 \mu \mathrm{M}$ were not tested. 

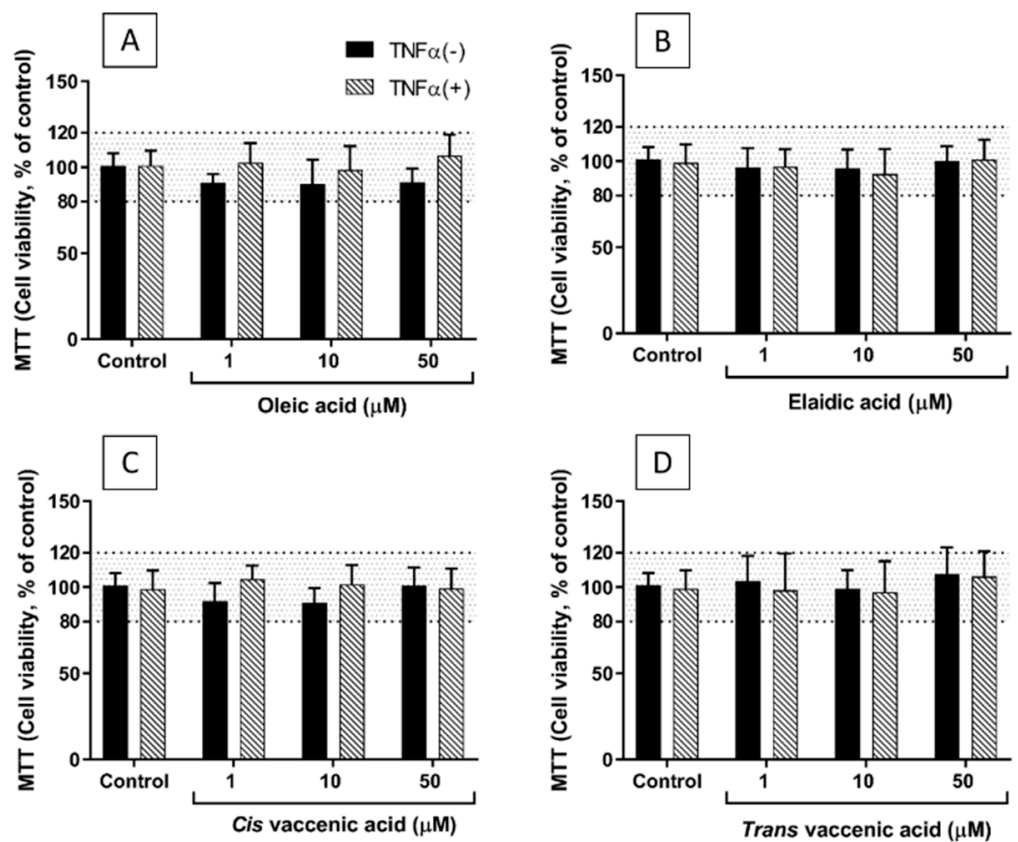

Figure 1. Viability of EA.hy926 cells after preincubation for $48 \mathrm{~h}$ with supplemented DMEM containing $0.1 \%$ of ethanol (Control) or different concentrations $(1,10$, and $50 \mu \mathrm{M})$ of oleic acid (A), elaidic acid (B), cis vaccenic acid (C), or trans vaccenic acid (D), followed by incubation with $(+)$ or without (-) TNF- $\alpha(1 \mathrm{ng} / \mathrm{mL})$ for $24 \mathrm{~h}$. Bars are mean \pm SEM of 9 samples performed in 3 experiments. Data were analysed using two-way ANOVA with Tukey's post hoc test. There were no significant effects observed.

\subsection{FA Incorporation into EA.hy926 Cells}

Figure 2 shows that the incorporation of each of the studied FAs into EA.hy926 cells increased as their concentration in the culture medium increased from 1 to $50 \mu \mathrm{M}$. CVA was incorporated in a higher amount than TVA, while OA and EA were incorporated to a similar extent.
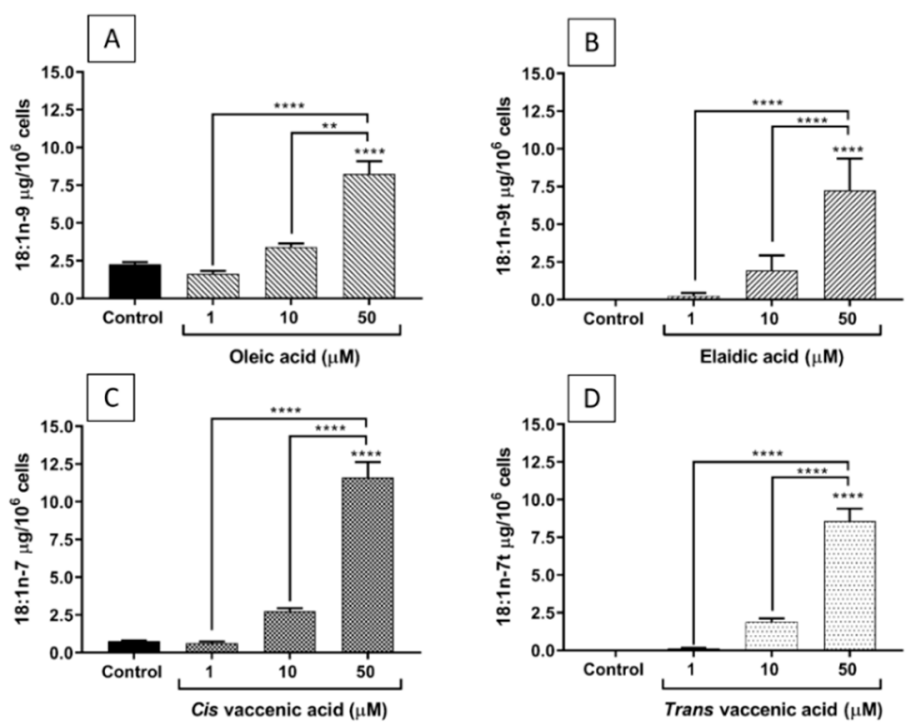

Figure 2. Incorporation of FAs into EA.hy926 cells incubated for $48 \mathrm{~h}$ with DMEM containing $0.1 \%$ of ethanol (Control) or different concentrations $(1,10$, and $50 \mu \mathrm{M})$ of oleic acid (A), elaidic acid (B), cis vaccenic acid (C), or trans vaccenic acid (D). Bars are mean \pm SEM of 6 to 9 samples performed in 3 experiments. Data were analysed using one-way ANOVA with Tukey's post hoc test. ${ }^{* *} p<0.01$; **** $p<0.0001$ between groups indicated by joined lines or vs. Control when there is no joined line. 


\subsection{Effects of FAs on the Levels of Inflammatory Mediators Produced by ECs}

Figure 3A shows that preincubation of EA.hy926 cells with any of the four FAs at a concentration of 1 or $10 \mu \mathrm{M}$ prior to TNF- $\alpha$ stimulation did not induce changes in the supernatant levels of monocyte chemoattractant protein (MCP)-1 compared to control (i.e., TNF- $\alpha$ without any FA preincubation). However, preincubation with $50 \mu \mathrm{M}$ EA prior to TNF- $\alpha$ stimulation produced a significant increase of MCP-1 levels, compared to control and to TVA pretreated cells (both $p<0.001$ ).
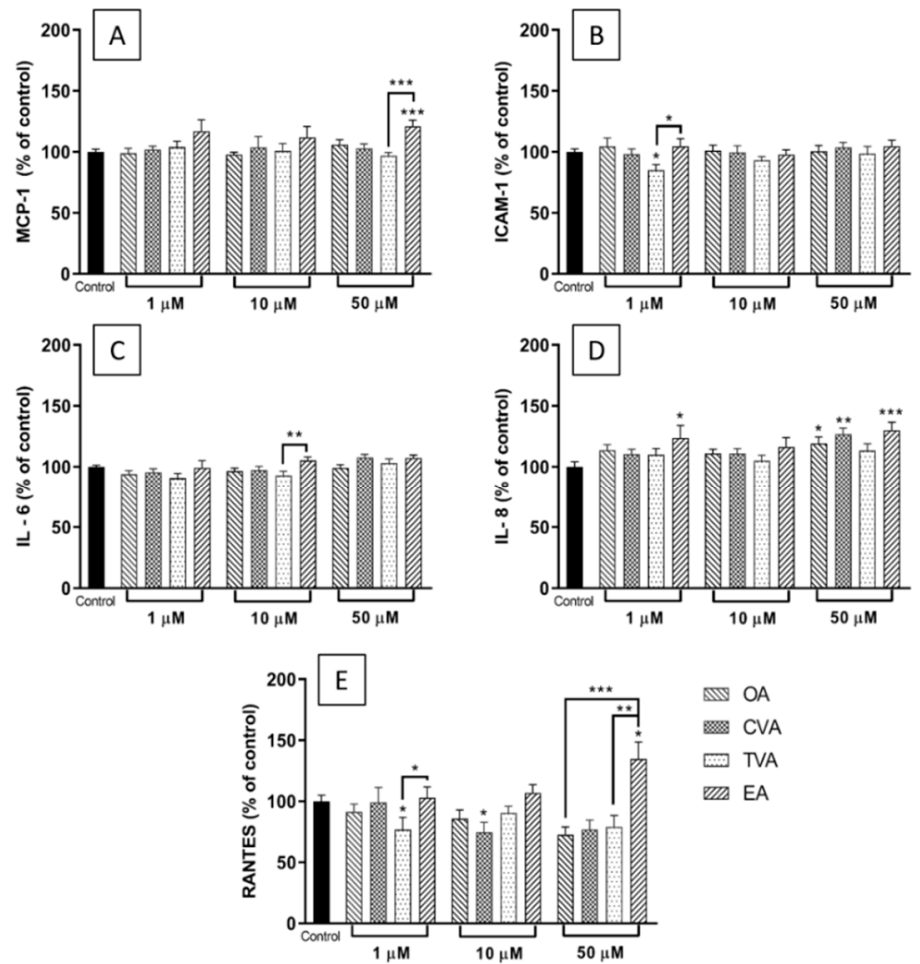

Figure 3. Concentrations (\% of control) of MCP-1 (A), ICAM-1 (B), IL-6 (C), IL-8 (D), and RANTES (E) in the medium of EA.hy926 cells preincubated for $48 \mathrm{~h}$ with DMEM containing $0.1 \%$ of ethanol (Control) or FA at 1, 20, or $50 \mu \mathrm{M}$, followed by incubation with TNF- $\alpha(1 \mathrm{ng} / \mathrm{mL})$ for $24 \mathrm{~h}$. Bars are mean \pm SEM of 9 samples from 3 experiments. Data were analysed using one-way ANOVA with Tukey's post hoc test. ${ }^{*} p<0.05 ;{ }^{* *} p<0.01 ;{ }^{* * *} p<0.001$ between groups indicated by joined lines or vs. Control when there is no joined line. $\mathrm{OA}=$ oleic acid, $\mathrm{CVA}=$ cis vaccenic acid, $\mathrm{TVA}=$ trans vaccenic acid, EA = elaidic acid.

Preincubation with TVA at $1 \mu \mathrm{M}$ produced significant decreases in the supernatant levels of intercellular adhesion molecule (ICAM)- 1 in response to TNF- $\alpha$, compared to control and to EA pretreated cells (both $p<0.05$ ) (Figure 3B).

FA preincubation did not induce significant changes in TNF- $\alpha$ induced interleukin (IL)-6 levels compared to control, although preincubation with EA at $10 \mu \mathrm{M}$ prior to TNF- $\alpha$ stimulation resulted in higher IL-6 levels than preincubation with TVA $(p<0.01)$ (Figure 3C).

Preincubation with EA at 1 or $50 \mu \mathrm{M}$ before TNF- $\alpha$ stimulation produced a significant increase in IL-8 levels in the supernatant compared with control $(p<0.05$ and $p<0.001$, respectively), which was also the case for OA and CVA at $50 \mu \mathrm{M}(p<0.05$ and $p<0.01$, respectively) (Figure 3D).

For regulated upon activation, normal $\mathrm{T}$ cell expressed and presumably secreted (RANTES), preincubation with CVA or TVA induced significant changes compared with control, with decreased levels compared to control for CVA at $10 \mu \mathrm{M}(p<0.05)$ and for TVA at $1 \mu \mathrm{M}(p<0.05)$. Additionally, preincubation with $50 \mu \mathrm{M}$ EA significantly increased 
levels of RANTES compared to control $(p<0.05)$, and compared to preincubation with OA or TVA ( $p<0.001$ and $p<0.01$, respectively) (Figure 3E).

\subsection{Effects of FAs on the Expression of Inflammation-Related Genes}

TNF- $\alpha$ stimulation is well known to activate the nuclear factor kappa-light-chainenhancer of activated B cells (NFKB) signalling pathway, resulting in NFKB translocation to the nucleus and upregulation of genes encoding multiple inflammatory cytokines and chemokines including MCP-1, IL-6, IL-8, and RANTES as well as other inflammatory proteins including those encoding toll-like receptor (TLR)-4 and cyclooxygenase (COX)-2 (PTGS2). In addition, TNF- $\alpha$ induces expression of the NFKB1 gene as part of the process of regulating inflammation; hence, as well as expression of cytokine, chemokine, TLR-4 and COX-2 genes, expression of the NFKB1 gene can be used to monitor inflammation in response to TNF- $\alpha$ and to test the effects of potential pro- and anti-inflammatory interventions. Stimulation of ECs with TNF- $\alpha$ induced a time-dependent increase in NFKB1 mRNA (Figure 4).

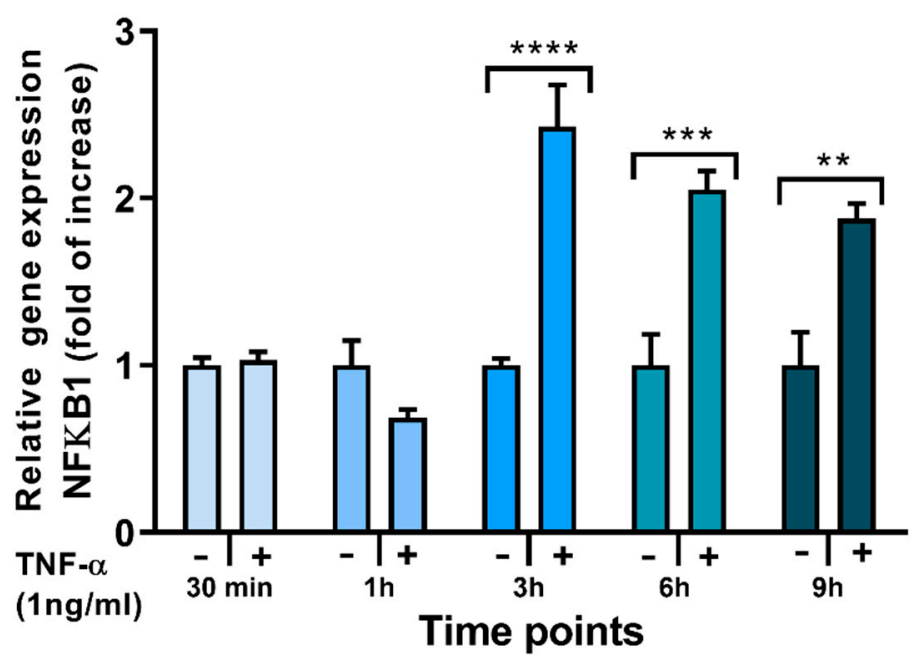

Figure 4. Expression of the NFK $\beta 1$ gene in EA.hy926 cells stimulated (+) with TNF- $\alpha(1 \mathrm{ng} / \mathrm{mL})$ for different times up to $9 \mathrm{~h}$ or not stimulated (-). Cq values were normalised by the geometric mean of reference targets RPL13A and CYC1 genes. Bars are mean \pm SEM of 3 samples from 1 experiment. Stimulated and unstimulated cells were compared at each time point by Student's $t$-test. ${ }^{* *} p<0.01$, ${ }^{* * *} p<0.001,{ }^{* * * *} p<0.001$ for stimulated vs. unstimulated cells.

As shown in Figure 5A, preincubation with TVA at $1 \mu \mathrm{M}$ reduced the relative expression of NFKB1 mRNA following TNF- $\alpha$ stimulation compared to what was seen with the TNF- $\alpha$ stimulated control cells $(p<0.05)$. The other FAs used did not induce any changes in NFkB1 relative expression. 

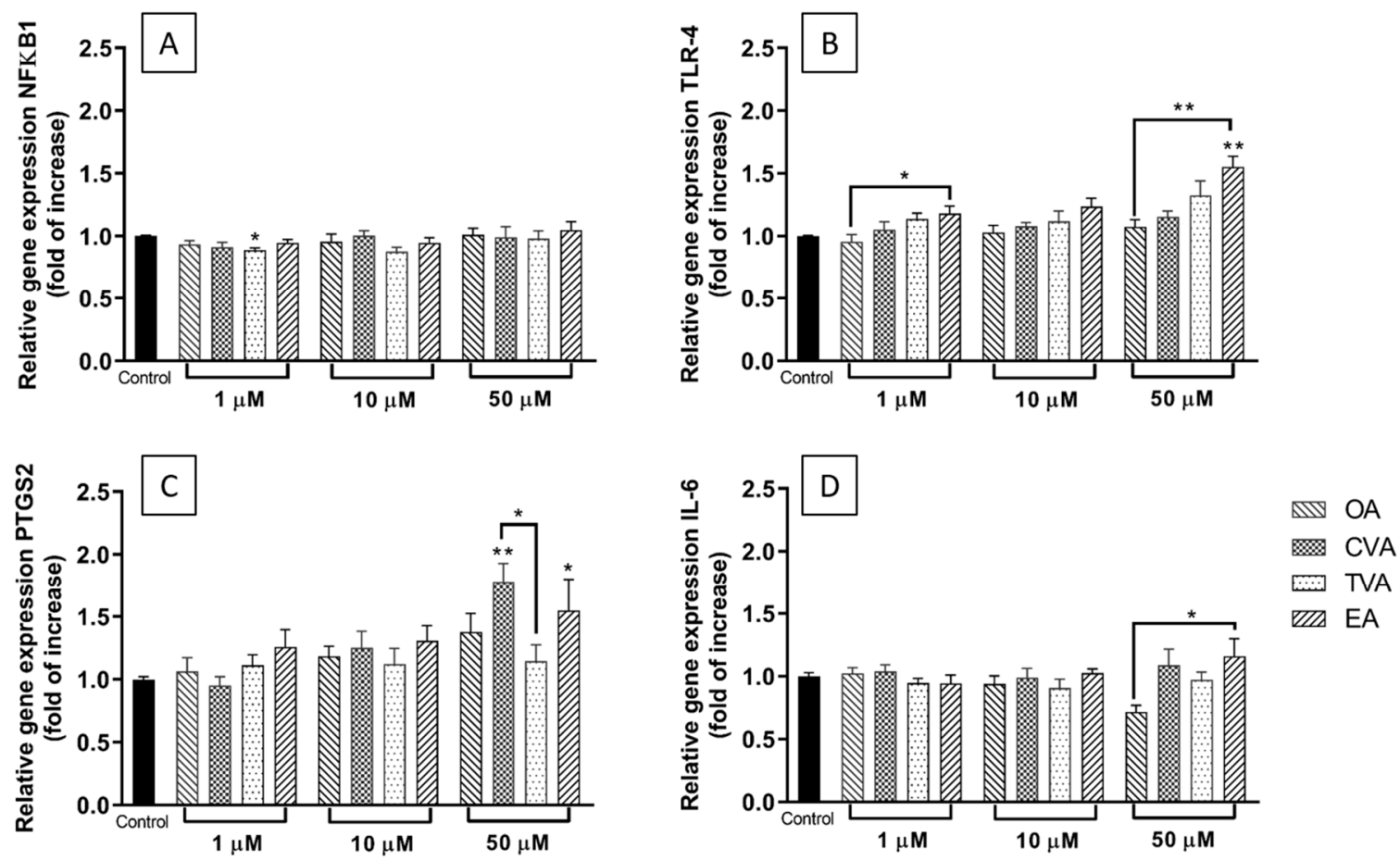

Figure 5. Expression of NFk $\beta 1$ (A), TLR-4 (B), PTGS2 (C), and IL-6 (D) genes in EA.hy926 cells preincubated for $48 \mathrm{~h}$ with 1 , 10 , and $50 \mu \mathrm{M}$ of FA in DMEM containing $0.1 \%$ of ethanol (Control) followed by incubation with TNF- $\alpha(1 \mathrm{ng} / \mathrm{mL})$ for $6 \mathrm{~h}$. Cq values were normalised by the geometric mean of reference targets RPL13A and CYC1 genes. Bars are mean \pm SEM of 9 samples performed in 3 experiments. Data were analysed using one-way ANOVA with Tukey's as post hoc test. ${ }^{*} p<0.05$, ${ }^{* *} p<0.01$ between groups indicated by joined lines or vs. Control when there is no joined line. OA $=$ oleic acid, $\mathrm{CVA}=c i s$ vaccenic acid, TVA = trans vaccenic acid, $\mathrm{EA}=$ elaidic acid.

Figure $5 \mathrm{~B}$ shows that preincubation with $\mathrm{EA}$ at $1 \mu \mathrm{M}$ increased TLR-4 gene expression following TNF- $\alpha$ stimulation compared to its cis-isomer OA $(p<0.05)$, while at $50 \mu \mathrm{M}$, the increase was significantly different from that with control or OA pretreated cells (both $p<0.01)$.

For the gene encoding cyclooxygenase COX-2 (PTGS2), only the highest FA concentration produced significant modulation: preincubation with either CVA or EA induced an increase in COX-2 gene expression following TNF- $\alpha$ stimulation compared to control (Figure 5C, $p<0.05$ and $p<0.01$, respectively). Additionally, the level was higher with CVA than with TVA $(p<0.05)$.

Preincubation with EA at a concentration of $10 \mu \mathrm{M}$ increased TNF- $\alpha$ induced IL-6 gene expression compared to preincubation with OA (Figure 5D).

\subsection{Effects of FAs on THP-1 Adhesion to EA.hy926 Cells}

As shown in Figure 6A, preincubation of EA.hy926 cells with TVA, OA, or CVA at $1 \mu \mathrm{M}$ for $48 \mathrm{~h}$ prior to TNF- $\alpha$ stimulation decreased the subsequent adhesion of THP-1 monocytes compared to control ( $p<0.001, p<0.05$, and $p<0.01$, respectively). When the FAs were used at $10 \mu \mathrm{M}$, none of them induced changes in monocyte adhesion compared to control (Figure 6B). Preincubation with EA at $50 \mu \mathrm{M}$ increased monocyte adhesion compared to control $(p<0.05)$ and TVA pretreated cells $(p<0.05)$ (Figure 6C). 

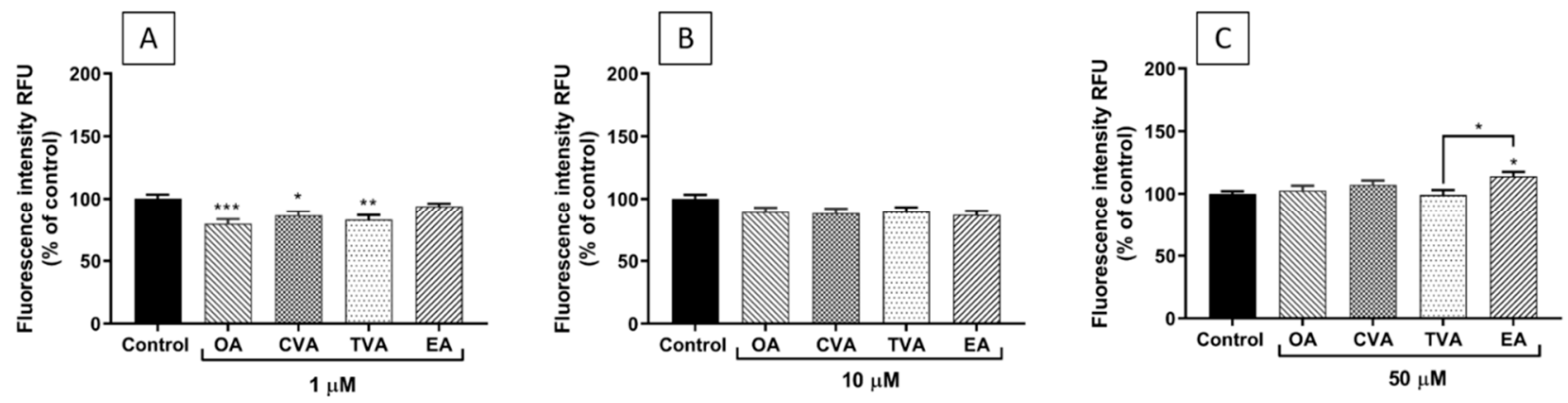

Figure 6. Adhesion of THP-1 cells (\% of control) to EA.hy 926 cells incubated for $48 \mathrm{~h}$ with DMEM containing $0.1 \%$ of ethanol (Control) or different concentrations $(1 \mu \mathrm{M}(\mathbf{A}), 10 \mu \mathrm{M}(\mathbf{B}), 50 \mu \mathrm{M}(\mathbf{C}))$ of FA, followed by incubation with TNF- $\alpha(1 \mathrm{ng} / \mathrm{mL})$ for $24 \mathrm{~h}$ and then $1 \mathrm{~h}$ co-incubation with THP-1 cells. Bars are mean \pm SEM of 9 samples performed in 3 experiments. Data were analysed using one-way ANOVA with Tukey post hoc test. ${ }^{*} p<0.05$; ${ }^{* *} p<0.01$; ${ }^{* * *} p<0.001$ between groups indicated by joined lines or vs. Control when there is no joined line. OA = oleic acid, CVA $=$ cis vaccenic acid, TVA $=$ trans vaccenic acid, EA = elaidic acid.

Images taken under the fluorescence microscope agree with the quantitative results, showing a higher number of THP-1 monocytes (green spots) when ECs were preincubated with EA (Figure 7).
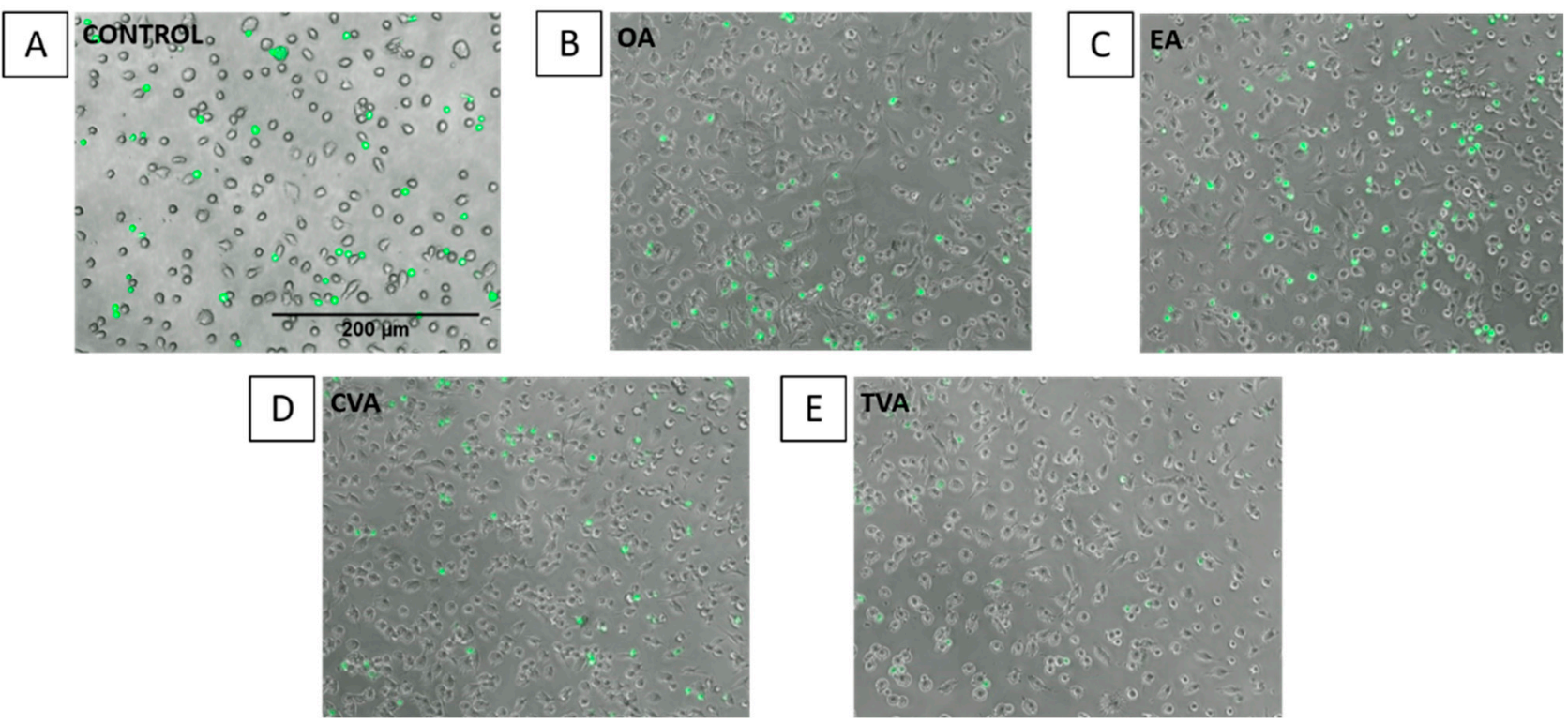

Figure 7. Images of THP-1 cell adhesion to EA.hy926 cells. Adhesion of THP-1 cells to EA.hy926 cells without preincubation with FA (control (A)) or with $48 \mathrm{~h}$ prior exposure to $50 \mu \mathrm{M}$ oleic acid (B), elaidic acid (C), cis vaccenic acid (D), or trans vaccenic acid (E), followed by incubation with TNF- $\alpha(1 \mathrm{ng} / \mathrm{mL})$ for $6 \mathrm{~h}$ and then $1 \mathrm{~h}$ co-incubation with calcein-labelled THP-1 cells. Attached THP-1 cells were visualised by fluorescence microscopy (Nikon Elipse Ti) at a magnification of $100 \times$ under transmitted light.

\subsection{Effects of FAs on the Expression of ICAM-1 on the Surface of EA.hy926 Cells}

Incubation of EA.hy926 cells with TNF- $\alpha$ significantly upregulated cell surface ICAM1 expression (Figure 8). 
A

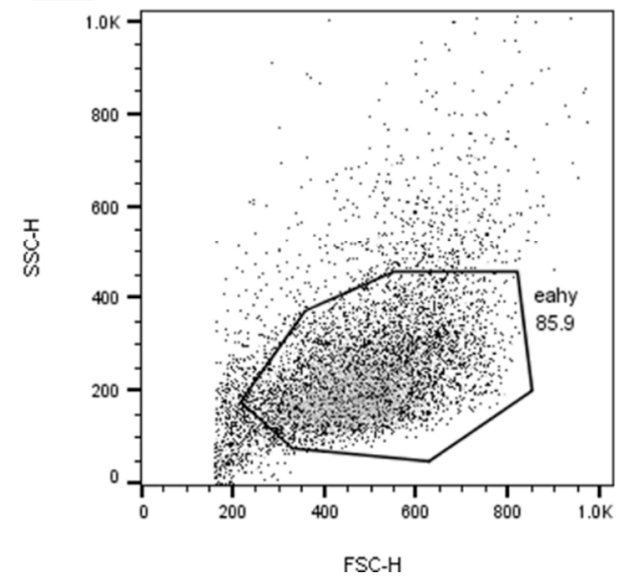

B

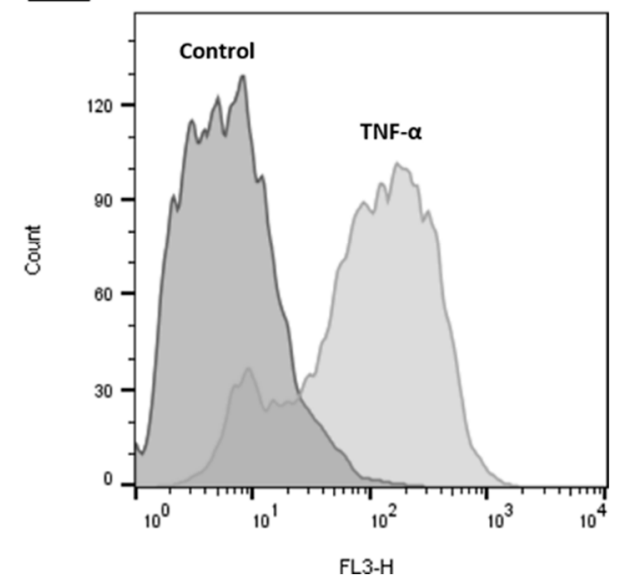

Figure 8. Flow cytometry plots for cell surface ICAM-1 analysis. (A) Gated unstained TNF- $\alpha$ stimulated EA.hy 926 cells. (B) Gated unstimulated (Control) and TNF- $\alpha$ stimulated (PE-CyTM 5)-conjugated CD54 (ICAM-1) antibody stained EA.hy926 cells.

Preincubation with FAs prior to TNF- $\alpha$ stimulation was shown to have differential effects on surface ICAM-1 expression depending on the individual FA and on FA concentration. Preincubation with TVA showed a trend to reduce the $\%$ of cells expressing ICAM-1 with all the concentrations used, behaving significantly differently from EA (Figure 9A-C, $p<0.05, p<0.0001$, and $p<0.001$, respectively).
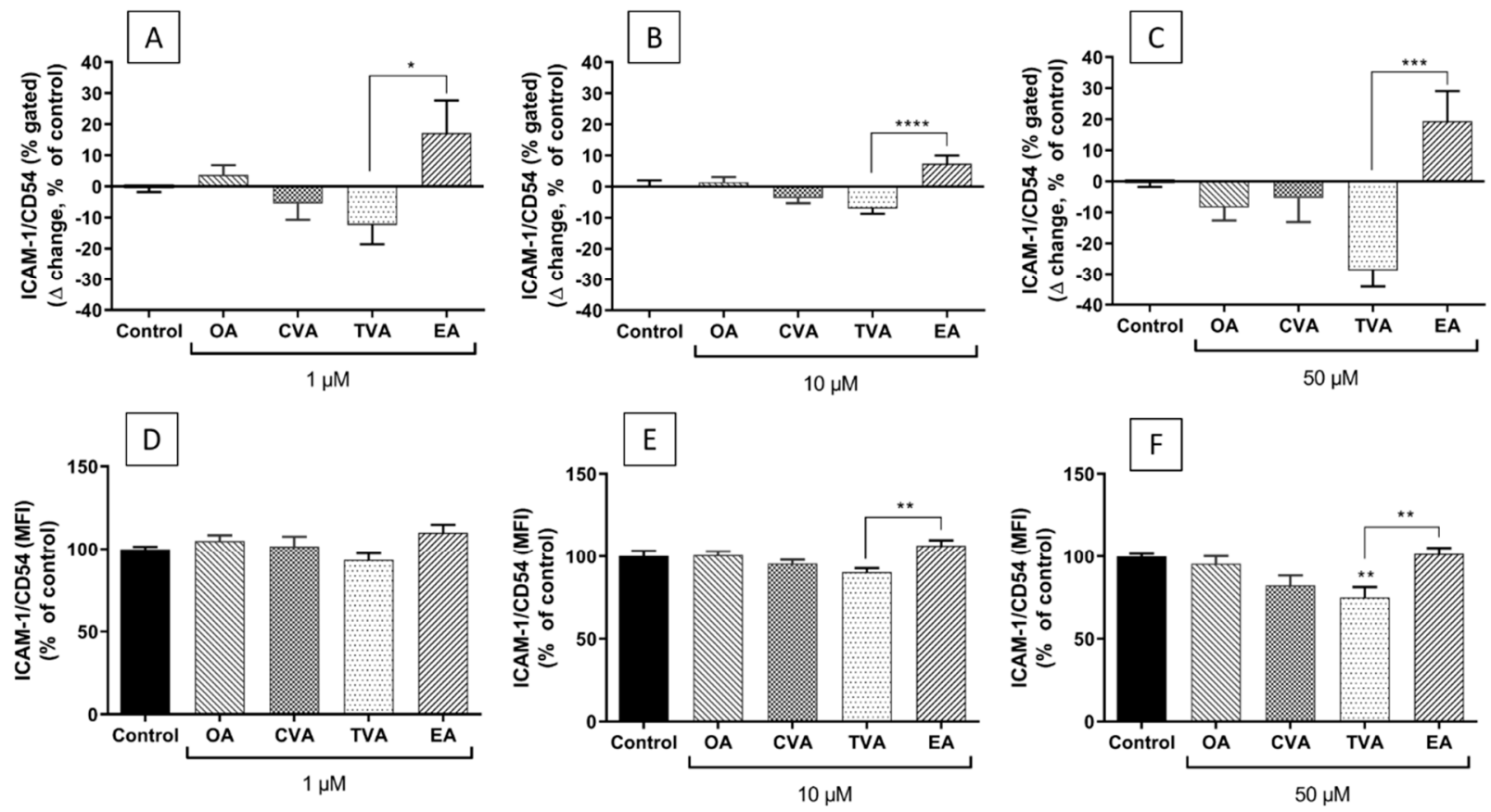

Figure 9. Cell surface expression of ICAM- 1 as \% of EA.hy926 cells gated ( $\Delta$ change, $\%$ of control) (A-C) and as median fluorescence intensity (MFI, \% of control) (D-F) after preincubation for $48 \mathrm{~h}$ with DMEM containing $0.1 \%$ ethanol (Control) or different concentrations $(1 \mu \mathrm{M} ; 10 \mu \mathrm{M} ; 50 \mu \mathrm{M})$ of FA, followed by incubation with TNF- $\alpha(1 \mathrm{ng} / \mathrm{mL})$ for $6 \mathrm{~h}$. Bars are mean \pm SEM of 9 samples performed in 3 experiments. Data were analysed using one-way ANOVA with Tukey's post hoc test. ${ }^{*} p<0.05 ;{ }^{* *} p<0.01$; ${ }^{* * *} p<0.001{ }^{* * * *} p<0.0001$ between groups indicated by joined lines or vs. Control when there is no joined line. $\mathrm{OA}=$ oleic acid, $\mathrm{CVA}=$ cis vaccenic acid, TVA = trans vaccenic acid, EA = elaidic acid. 
The differences in the \% of cells expressing ICAM-1 were consistent with the differences in the levels of ICAM-1 expression on the surface of positive cells (i.e., MFI). As shown in Figure 9D-F, preincubation with TVA tended to reduce the level of ICAM-1 expression on EA.hy926 cells subsequently stimulated with TNF- $\alpha$, inducing a significant effect when used at $50 \mu \mathrm{M}(p<0.01)$. Preincubation with EA tended to induce the opposite effect, behaving significantly differently from TVA when used at 10 and $50 \mu \mathrm{M}$ (both $p<0.01)$.

\section{Discussion}

With the purpose of understanding the possible differential effects and mechanisms through which TFAs could affect normal functioning of human endothelial tissues in relation to CVD development, the present study compared the effects of 18-carbon cis and trans FA isomers on the inflammatory response in cultured EA.hy926 ECs. These cells are derived from human umbilical vein ECs, which are perhaps the most widely studied type of EC. Their responses to inflammatory stimuli are similar to those seen with ECs from adults [23]. The effects of the TFAs were investigated using cells subsequently stimulated with TNF- $\alpha$, indicating the ability of the TFAs to modulate the response to a classic inflammatory stimulus. In all cases, effects of TFAs were compared to cells incubated without additional FAs and to cells exposed to comparator 18-carbon cis FAs. Overall, this study showed differential effects of the FAs tested, mainly in terms of the effects of ruminant vs. industrial 18-carbon TFAs, and some differences between the cis and trans isomers.

In relation to the effects of the FAs on the production of inflammatory mediators by ECs, preincubation with EA increased or tended to increase the levels of most of the cytokines, chemokines, and adhesion molecules measured after inflammatory stimulation, while TVA showed a neutral effect. These results are consistent with the findings on gene expression. Here preincubation with EA induced a significantly enhanced upregulation of TLR-4 and COX-2 gene expression when used at $50 \mu \mathrm{M}$, which could be considered as pro-inflammatory. In contrast, preincubation with TVA induced a significant reduction in the NFKB1 gene expression when used at $1 \mu \mathrm{M}$ and tended to do the same when used at $10 \mu \mathrm{M}$, which could be considered as anti-inflammatory.

When adhesion of monocytes (THP-1 cells) to the endothelial monolayer and the expression of ICAM-1 on the endothelial cell surface were assessed, differences between EA and TVA were also observed. Preincubation with EA induced a significant increase of THP-1 cell adhesion to ECs when used at $50 \mu \mathrm{M}$. EA showed a trend to increase both the $\%$ of gated ICAM-1 positive cells and the level of surface expression of ICAM- 1 at all the concentrations used. Again, these effects could be regarded as pro-inflammatory and pro-atherogenic. In contrast, preincubation with TVA reduced THP-1 monocyte adhesion when used at $1 \mu \mathrm{M}$ and tended to decrease both the $\%$ of gated ICAM- 1 positive cells and the level of surface expression of ICAM-1 at all the concentrations used, reducing the latter significantly when used at $50 \mu \mathrm{M}$. These effects could be considered to be anti-atherogenic.

The current study suggests that EA and TVA have opposite effects on EC responses to inflammatory stimulation. Several studies have described that EA and other iTFAs have deleterious effects on health outcomes in humans: a high dietary intake or high blood/tissue levels were associated with CHD, systemic inflammation, endothelial dysfunction, and possibly inflammation in the central nervous system [15,24-27]. Accordingly, a recent study showed a positive association between plasma EA levels with long-term total mortality in a subset of NHANES participants (cycle 1999-2000) [28]. Animal models have shown that EA enhances inflammatory parameters in cerebrospinal fluid and blood, increases insulin resistance, alters lipid profiles, and causes hepatic damage [29,30]. In vitro studies have described that EA $(100 \mu \mathrm{M})$ induces the expression of ICAM-1 and vascular cell adhesion molecule (VCAM)-1 on the surface of aortic ECs, increases the expression of ICAM-1 and VCAM-1 mRNA, and also leukocyte adhesion, phosphorylation of NFkB, and reactive oxygen species generation in these cells [18]. Experiments with another human 
EC model (microvascular ECs) showed that exposure to EA $(100 \mu \mathrm{M})$ increased NFkB activation as measured by IL-6 levels and phosphorylation of I $\mathrm{B} \alpha$, increased superoxide production, and impaired insulin signaling and nitric oxide production [17], suggesting pro-inflammatory actions of EA. In the current study, using a maximum concentration that is half of what other authors have used $(50 \mu \mathrm{M})$, it was shown that EA exposure to EA.hy926 cells increased inflammatory mediator levels (MCP-1, RANTES, and IL-8) in response to TNF- $\alpha$. Increased levels of these mediators are related to a pro-inflammatory state that could lead to the development of atherosclerosis and endothelial dysfunction. For example, MCP-1 is one of the key chemokines that regulate migration and infiltration of monocytes/macrophages into the subendothelial space, being considered an early indicator of endothelial dysfunction [31].

EA also showed a trend to enhance TNF- $\alpha$-induced surface expression of ICAM-1. This adhesion molecule is involved in the leukocyte-endothelium interaction and the regulation of vascular permeability [32]. Because adhesion is one of the earliest steps of inflammation in atherosclerosis, followed by migration of blood leukocytes into the subendothelial space, the increase in adhesive properties of ECs may be an important mechanism by which dietary iTFAs exert their pro-inflammatory and pro-atherogenic effects [18]. In agreement with this, EA induced a significant increase of THP-1 cell adhesion to ECs.

The evidence about the health-related effects of rTFAs is not consistent, especially when comparing the results from animal models with outcomes in human studies. It has been shown that TVA can lower fasting triglycerides, total cholesterol, LDL cholesterol, and non-esterified FAs in animal models of dyslipidaemia [33-35]. Blewett et al. [36] also reported that short-term ( $3 \mathrm{wk}$ ) supplementation with TVA $(1.5 \% w / w)$ normalised stimulated IL-2 and TNF- $\alpha$ production and increased IL-10 production in JCR-LA-cp rats, suggesting anti-inflammatory effects. In humans, the literature is inconsistent. While some authors have reported beneficial effects of rTFAs, others have shown opposite results. For example, Da Silva et al. [37] compared iTFA and rTFA in plasma phospholipids and their correlations with metabolic risk factors, including lipid profile, glycaemic profile, adiposity, and blood pressure, in a cohort composed of 100 healthy non-obese and 100 obese participants. They found that plasma rTFAs (TVA and trans palmitoleic acid) were associated with lower insulin levels and blood pressure and higher adiponectin levels, unlike their industrial counterpart (EA) which was associated with higher total cholesterol, triglycerides, and glycaemia [37]. On the other hand, Gebauer et al. [38] conducted a double-blind, randomised, crossover feeding trial in 106 healthy adults. They determined the effects of TVA, a conjugated linoleic acid (CLA9,11), and EA, in the context of highly controlled diets, on lipoprotein risk factors compared with a control diet. Their findings showed that both TVA and partially hydrogenated vegetable oil adversely affect atherogenic lipoproteins, with higher concentrations of LDL cholesterol, apoB, and triacylglycerol [38]. In contrast, studies in endothelial and other cell line models have reported beneficial effects of TVA $[17,20,39,40]$, concordant to some extent with the results presented in the current study. Overall, this study showed that while the levels of the inflammatory mediators measured did not change with the exposure of the ECs to TVA, the cell surface expression of ICAM-1 decreased significantly at the highest TVA concentration used $(50 \mu \mathrm{M})$.

Even though other studies have reported outcomes related to inflammation in relation to exposure to TVA, they are not the same outcomes as measured in the current research, which makes the comparison with other findings considerably harder in comparison to EA. For instance, a study on human microvascular ECs reported that TVA $(100 \mu \mathrm{M})$ did not induce any inflammatory responses in comparison to EA and linoelaidic acid, specifically in relation to NFKB activation, levels of IL-6, and superoxide production [17]. Another study using human peripheral blood mononuclear cells showed that TVA decreased the percentage of both IL-2 and TNF- $\alpha$ expressing T-helper cells induced by alloreactive stimulation [39]. Krogager et al. [40] showed that TVA had no effect on proliferation of HepG2-SF cells or their metabolism of cholesterol in comparison to EA, assessed by proteome analysis. The study by Da Silva et al. [21] showed that TVA at concentrations 
above $25 \mu \mathrm{M}$ significantly reduced the TNF- $\alpha$ induced expression of TNF- $\alpha$, VCAM- 1 , and superoxide dismutase 2 genes in HUVECs. The same study reported that TVA induced a reduction in the gene expression of IL-8 and TNF in HepG2 cells [21]. Another recent study in HUVECs showed an increased protein expression of ICAM-1, VCAM-1, IL-6, and COX-2 and increased prostaglandin $\mathrm{E}_{2}$ secretion in cells exposed to TVA or EA (100 $\mu \mathrm{M}$ for $24 \mathrm{~h}$ ) compared to control, although the inflammatory responses induced by EA were significantly higher than the ones observed with the TVA treatment. This study also reported that these TFAs induced reduced cell viability and cell membrane damage [41], in agreement with our observations for these two FAs at $100 \mu \mathrm{M}$.

In terms of the mechanism of action of these FAs, it seems plausible that TLR- 4 and NFKB are involved. Preincubation with EA induced an increase in mRNA expression of TLR-4 and COX-2 in response to stimulation with TNF- $\alpha$, but had no effect on NFKB1 mRNA expression. The TLR-4 pathway eventually activates NFKB signalling [42], which involves rapid increases in NFKB phosphorylation and nuclear translocation, and later (post $3 \mathrm{~h}$ stimulation) higher gene expression of NFKB genes. In the current study, EA did not affect NFkB1 gene expression $6 \mathrm{~h}$ post-TNF- $\alpha$ stimulation. We did not measure I $\kappa B$ or NFKB phosphorylation or NFKB translocation to the nucleus, so an effect of EA on the $N F \kappa B$ signalling pathway cannot be ruled out. Other authors have suggested that EA exerts pro-inflammatory actions in HUVECs through increased TLR-4 protein expression within lipid rafts [19]. The increased TLR-4 observed with preincubation with EA in the current study supports this, but we did not measure membrane levels of TLR-4 or TLR-4 associated with lipid rafts. Future investigations of the mechanism of action of EA in ECs should focus on these early signalling events. Although TVA had no effect at higher concentrations, at $1 \mu \mathrm{M}$ it was able to reduce NFKB1 relative gene expression in TNF- $\alpha$ stimulated ECs.

The difference between the findings shown here and those of other studies can be related to the FA concentrations and cell line used and other experimental/methodological differences. In addition, other authors may not check the concentrations of the FAs used periodically or even at all. While conducting the current research, it was observed that TFAs can be unstable when stored, so not knowing precisely the FA concentration used in in vitro studies is not a negligible factor when analysing the effects of TFAs. In relation to the FA concentrations used in this study, a maximum of $50 \mu \mathrm{M}$ was considered to avoid the toxic effects observed at $100 \mu \mathrm{M}$ (indicated by lower cell viability at this concentration). It is important to consider that most of the studies in the literature use TFA concentrations of $100 \mu \mathrm{M}$ average, reaching maximum values of $400 \mu \mathrm{M}$ [43]. It is important to consider whether these concentrations are physiologically achievable and comparable to the amount of TFA that can be incorporated into human cells and tissues through the diet. There is limited information on this. Nevertheless, the highest TFAs levels reported in plasma in healthy adults correspond to $88 \mu \mathrm{M}$ for EA and $74 \mu \mathrm{M}$ for TVA [44].

In common with other FAs, TFAs are likely to exert most of their effects on inflammation following incorporation into the cell membrane [13]. From here they can potentially influence membrane fluidity, membrane protein function, lipid raft formation, and the generation of intracellular signals [13]. These effects may, in turn, affect transcription factors and gene expression [13]. It might be anticipated that the effects of FAs on inflammatory cell responses will be concentration dependent, because their incorporation into cells is concentration dependent, as demonstrated here for all four FAs investigated (Figure 2). As discussed already, EA had the most marked and consistent effects on ECs in the current study and these may be generally viewed as enhancing the response to the inflammatory stimulus TNF- $\alpha$. EA had its greatest effects on MCP-1, IL-8, and RANTES production, on TLR-4 and PTGS2 gene expression, on THP-1 cell binding, and on ICAM-1 expression when used at a concentration of $50 \mu \mathrm{M}$. Although, some of these effects do appear to be concentration dependent, in some cases (ICAM-1, IL-8, and RANTES production) EA had a significant effect at $1 \mu \mathrm{M}$, but not at $10 \mu \mathrm{M}$. The reason for this is not immediately apparent but it may relate to the relatively small number of replicates and/or to inherent variations between the individual experiments including the precise incorporation of the FAs into 
the ECs. What is evident is that quite marked incorporation of the different FAs occurred when they were used at a concentration of $50 \mu \mathrm{M}$ and it was at this concentration that the effects of EA (and TVA) were most marked. Thus, it seems likely that the effects of TFAs on inflammation are concentration dependent but that these effects may not become apparent until sufficient FA is incorporated into the cells.

In summary, the results of this study indicate that the ruminant-derived TVA has the potential to reduce some inflammatory responses of ECs related to atherosclerosis. In contrast, EA increased inflammatory responses of ECs to TNF- $\alpha$ stimulation. These findings suggest differential effects induced by the TFAs tested fitting with the idea that iTFAs and rTFAs can have different and perhaps opposing biological actions. The mechanisms through which these FAs influence the inflammatory response in ECs need further exploration, although TLR-4 and NFKB pathways are likely to be involved.

\section{Materials and Methods}

\subsection{Endothelial Cell Model}

EA.hy926 cells (ATCC, LGC standards, Middlesex, UK) were cultured in high glucose Dulbecco's Modified Eagle Medium (DMEM) supplemented with 10\% fetal bovine serum, $1 \%$ L-glutamine-penicillin-streptomycin solution, and 1\% HAT (100 $\mu \mathrm{M}$ hypoxanthine, $0.4 \mu \mathrm{M}$ aminopterin and $16 \mu \mathrm{M}$ thymidine); medium and supplements were purchased from Sigma-Aldrich (Gillingham, UK). Cultures were maintained at $37^{\circ} \mathrm{C}$ in humidified $95 \%$ air and $5 \% \mathrm{CO}_{2}$. Before their use in experiments, cells were grown in T-175 flasks until confluent.

\subsection{Fatty Acid (FA) Treatment}

Trans vaccenic acid (TVA), elaidic acid (EA), cis vaccenic acid (CVA), and oleic acid (OA) (all from Cayman Chemicals, Cambridge, UK) were prepared as 1, 10, and $50 \mathrm{mM}$ stock solutions in 100\% ethanol. Before each experiment, the stock solutions were diluted in warm complete culture medium to yield final concentrations of 1,10 , and $50 \mu \mathrm{M}$. The corresponding control was a $0.1 \%$ ethanol solution diluted in complete medium. For the experiments, EA.hy926 cells were seeded in 96 well plates (for MTT assay and ELISA), 6 well plates (for RT-PCR, adhesion assay, flow cytometry), or T25 flasks (for gas chromatography), cultured in complete medium and exposed to different FAs for $48 \mathrm{~h}$. Based on the conditions optimised for studying inflammatory responses of cultured EA.hy926 cells, after the FA exposure period, cells were incubated with TNF- $\alpha(1 \mathrm{ng} / \mathrm{mL}$; 20 units $/ \mathrm{mL}$ ) for 6 or $24 \mathrm{~h}$, depending on the assay to be performed.

\subsection{MTT Assay for Cell Viability}

Cell viability was assessed using the 3-(4,5-dimethylthiazol-2-yl)-2,5diphenyltetrazolium bromide (MTT) assay which measures cellular mitochondrial activity. After the treatments, supernatant was removed and replaced with DMEM containing $0.05 \mathrm{mg} / \mathrm{mL}$ MTT (Sigma-Aldrich) $(100 \mu \mathrm{L} /$ well $)$ and samples incubated at $37^{\circ} \mathrm{C}$ for $4 \mathrm{~h}$. Supernatants $(75 \mu \mathrm{L})$ were removed and $75 \mu \mathrm{L}$ of dimethylsulphoxide (Sigma-Aldrich) added. Absorbance was measured at $540 \mathrm{~nm}$ on a plate reader. The effects of FAs and TNF- $\alpha$ on cell viability were normalized to control (i.e., no FA or TNF- $\alpha, 0.1 \%$ ethanol) cultures $(100 \%)$.

\subsection{Gas Chromatography}

The FA concentrations and the FA composition of EA.hy926 cells after culture with the FAs of interest were determined using gas chromatography. For FA concentration testing, each FA was diluted in full warm medium from the respective stock in $100 \%$ ethanol. For FA incorporation, cells were seeded in T25 flasks $\left(5 \times 10^{5}\right.$ cells $\left./ \mathrm{mL}\right)$ for $48 \mathrm{~h}$ with each FA at different concentrations. Afterwards, the cells were inspected under the microscope, scraped off, and counted with a Beckman Coulter cell counter. EA.hy926 cells were resuspended to have $1 \times 10^{6}$ cells $/ 800 \mu \mathrm{L}$ of $0.9 \% \mathrm{NaCl}$ solution. 
Total lipid was extracted from cell pellets and culture medium, after adding an internal standard (C21:0), using chloroform/methanol (2:1 v/v) and $\mathrm{NaCl}(1 \mathrm{M})$. Lipid extracts were dried under nitrogen at $40{ }^{\circ} \mathrm{C}$ and then resuspended in toluene. FAs were released from the isolated lipids and simultaneously methylated by heating with $2 \%$ sulphuric acid in methanol at $50{ }^{\circ} \mathrm{C}$ for $2 \mathrm{~h}$. The resulting FA methyl esters (FAMEs) were extracted into hexane and then separated and analysed by gas chromatography using conditions described by Fisk et al. [45]. FAME histograms produced were analysed with Agilent ChemStation software. Thirty-seven FAMEs were used as standard to identify FAs according to retention time and for software calibration. FAs are expressed as $\mu \mathrm{g} / 10^{6}$ cells.

\subsection{Multiplex Magnetic ELISA}

Cell culture supernatants were assayed by Human Magnetic Luminex Screening Assay ELISA (R\&D Systems, Minneapolis, MN, USA) to measure the concentration of inflammatory factors monocyte chemoattractant protein (MCP)-1, interleukin (IL)-6, IL-8, regulated upon activation, normal $\mathrm{T}$ cell expressed and presumably secreted (RANTES), and intercellular adhesion molecule (ICAM)-1. EA.hy926 cells were incubated with the FAs in 96 well plates $\left(1 \times 10^{4}\right.$ cells $/ 100 \mu \mathrm{L}$ per well $)$ for $48 \mathrm{~h}$ and then incubated with TNF- $\alpha$ for a further $24 \mathrm{~h}$. Before the supernatants of each well were collected and stored at $-80{ }^{\circ} \mathrm{C}$ until analysis, the cells were checked under the microscope. Assays were conducted in accordance with the instructions from the manufacturer. Plates were analysed on a calibrated Bio-Plex 200 analyser using Bio-Plex software (version 6.1, Bio-Rad Laboratories Inc., Berkeley, CA). Lower limits of detection (pg/mL) were IL-6, 1.7; IL-8, 1.8; MCP-1, 9.9; RANTES, 1.8; ICAM-1, 87.9. Due to differences in the ranges of fluorescence values among experiments, the results are presented as \% of control.

\subsection{RNA Isolation, cDNA Synthesis, and Real-Time PCR}

Changes in relative gene expression were analysed by RT-PCR. EA.hy926 cells were incubated with FAs for $48 \mathrm{~h}$ followed by incubation with TNF- $\alpha(1 \mathrm{ng} / \mathrm{mL})$ for $6 \mathrm{~h}$. Taqman Gene Expression Primers (ThermoFisher Scientific, Waltham, MA, USA) were used to determine the expression of nuclear factor kappa B subunit 1 (NFkB1) (Hs00765730_m1), toll-like receptor (TLR)-4 (Hs00152939_m1), cyclooxygenase (COX)-2 (Hs00153133_m1), and IL-6 (HS00985639_m1). Total RNA was extracted from the cells using the ReliaPrep RNA cell Miniprep System (Promega, Southampton, UK). RNA quantity and quality were analysed by NanoDrop. Analysis of RNA using an Agilent Bioanalyzer (RNA Total Eukaryote 2100 Nano) was performed to determine RNA integrity through RIN scores. cDNA was synthesised from total RNA using GoScript Reverse Transcriptase (Promega). Housekeeping reference genes were determined using a geNorm Kit (Primerdesign, Camberley, UK). Quantification of relative gene expression was analysed using YWHAZ, (Hs01122445_g1), CYC1 (Hs00357717_m1), and RPL13A (Hs04194366_g1) as housekeeping genes.

\subsection{THP-1 Monocyte Adhesion Assay}

The adhesion of monocytes (THP-1 cells) to EA.hy926 cells was determined using the Vybrant Cell Adhesion Assay Kit (ThermoFisher Scientific). EA.hy926 cells were seeded in 96-well flat bottom plates (density of $2 \times 10^{5}$ cells $/ \mathrm{mL}, 1 \times 10^{5}$ cell per well). After incubation with FAs for $48 \mathrm{~h}$ and then with TNF- $\alpha$ for $24 \mathrm{~h}$, calcein-labelled THP-1 cells $\left(5 \times 10^{4}\right.$ cells in $\left.100 \mu \mathrm{L}\right)$ were incubated with EA.hy926 cells for $1 \mathrm{~h}$ at $37^{\circ} \mathrm{C}$. Non-adherent THP-1 cells were removed by gentle washing, $100 \mu \mathrm{L}$ PBS added to each well and cocultures read on the Glomax Discover System (Promega). THP-1 monocyte adhesion was measured as a percentage of control (non-stimulated DMEM treated cells). Images of fluorescence-labelled THP-1 monocytes bound to EA.hy926 cells were taken with a Nikon Elipse Ti using NIS elements software (version 4.30). 


\subsection{Flow Cytometry}

The expression of ICAM-1 (CD54) on the surface of EA.hy926 cells was determined through flow cytometry. EA.hy926 cells were seeded in six well plates (density of $6 \times 10^{5}$ cells $/ \mathrm{mL}$ ). After incubation with FAs and then with TNF- $\alpha$, the cells were detached, centrifuged, and stained with $\mathrm{PE}-\mathrm{Cy}^{\mathrm{TM}}{ }^{5}$-conjugated monoclonal anti-human $\mathrm{CD} 54$ (BD Biosciences, San Jose, CA) diluted in staining solution ( $2 \%$ bovine serum albumin in PBS) for $30 \mathrm{~min}$ at $4{ }^{\circ} \mathrm{C}$ in darkness. Mouse IgG1 $\mathrm{K}\left(\mathrm{PE}-\mathrm{Cy}{ }^{\mathrm{TM}} 5\right)$ isotype was used as a negative control. After staining, cells were analysed by flow cytometry using a FACSCalibur flow cytometer (BD Biosciences). A total of 10,000 events were collected. Percentage of positive cells and median fluorescence intensity (MFI) were measured.

\subsection{Data Analysis}

Data are presented as mean \pm SEM and were analysed by two-way analysis of variance (two-way ANOVA) or one-way ANOVA, followed by post hoc tests of pairwise differences. Analyses were performed using GraphPad Prism 6.0. Differences were considered significant when $p<0.05$.

Author Contributions: Conceptualization, C.A.V. and P.C.C.; methodology, C.A.V., E.J.B. and C.O.D.S.; formal analysis, C.A.V.; investigation, C.A.V., E.J.B. and C.O.D.S.; writing-original draft preparation, C.A.V.; writing-review and editing, P.C.C. and E.A.M.; supervision, E.A.M. and P.C.C. All authors have read and agreed to the published version of the manuscript.

Funding: This research received no external funding.

Data Availability Statement: Data can be made available by contacting the corresponding author.

Acknowledgments: C.A.V. was supported by CONICYT (Comisión Nacional de Investigación Científica y Tecnológica, Gobierno de Chile) through its scholarship program Becas Chile. E.J.B. was supported by the Biotechnology and Biological Sciences Research Council under the Food Security Doctoral Training Programme and by the Faculty of Medicine, University of Southampton. C.O.D.S. was supported by the São Paulo Research Foundation (FAPESP).

Conflicts of Interest: P.C.C. acts as a consultant to BASF AS, Smartfish, DSM, Cargill, Danone/Nutricia, and Fresenius-Kabi. All other authors declare no conflict of interest.

\section{References}

1. WHO. Global Health Estimates 2016: Deaths by Cause, Age, Sex, by Country and by Region. 2000-2016; World Health Organization: Geneva, Switzerland, 2018.

2. Usman, A.; Ribatti, D.; Sadat, U.; Gillard, J.H. From lipid retention to immune-mediate inflammation and associated angiogenesis in the pathogenesis of atherosclerosis. J. Atheroscler. Thromb. 2015, 22, 739-749. [CrossRef]

3. Gregor, M.F.; Hotamisligil, G.S. Inflammatory mechanisms in obesity. Annu. Rev. Immunol 2011, 29, 415-445. [CrossRef]

4. Hotamisligil, G.S. Inflammation and metabolic disorders. Nature 2006, 444, 860-867. [CrossRef]

5. Davignon, J.; Ganz, P. Role of endothelial dysfunction in atherosclerosis. Circulation 2004, 109, III27-III32. [CrossRef]

6. Gimbrone, M.A., Jr.; García-Cardeña, G. Endothelial cell dysfunction and the pathobiology of atherosclerosis. Circ. Res. 2016, 118, 620-636. [CrossRef]

7. Mozaffarian, D.; Katan, M.B.; Ascherio, A.; Stampfer, M.J.; Willett, W.C. Trans fatty acids and cardiovascular disease. N. Engl. J. Med. 2006, 354, 1601-1613. [CrossRef] [PubMed]

8. Oh, K.; Hu, F.B.; Manson, J.E.; Stampfer, M.J.; Willett, W.C. Dietary fat intake and risk of coronary heart disease in women: 20 years of follow-up of the nurses' health study. Am. J. Epidemiol. 2005, 161, 672-679. [CrossRef] [PubMed]

9. Sun, Q.; Ma, J.; Campos, H.; Hankinson, S.E.; Manson, J.E.; Stampfer, M.J.; Rexrode, K.M.; Willett, W.C.; Hu, F.B. A prospective study of trans fatty acids in erythrocytes and risk of coronary heart disease. Circulation 2007, 115, 1858-1865. [CrossRef]

10. Li, H.; Zhang, Q.; Song, J.; Wang, A.; Zou, Y.; Ding, L.; Wen, Y. Plasma trans-fatty acids levels and mortality: A cohort study based on 1999-2000 National Health and Nutrition Examination Survey (NHANES). Lipids Health Dis. 2017, 16, 176. [CrossRef] [PubMed]

11. Joint, F.A.O.; Consultation, W.E. Fats and fatty acids in human nutrition. In Proceedings of the Joint FAO/WHO Expert Consultation, Geneva, Switzerland, 10-14 November 2008; Volume 55, pp. 5-7.

12. Ganguly, R.; Pierce, G.N. The toxicity of dietary trans fats. Food Chem. Toxicol. 2015, 78, 170-176. [CrossRef]

13. Valenzuela, C.A.; Baker, E.J.; Miles, E.A.; Calder, P.C. Eighteen-carbon trans fatty acids and inflammation in the context of atherosclerosis. Prog. Lipid Res. 2019, 76, 101009. [CrossRef] [PubMed] 
14. Mozaffarian, D.; Clarke, R. Quantitative effects on cardiovascular risk factors and coronary heart disease risk of replacing partially hydrogenated vegetable oils with other fats and oils. Eur. J. Clin. Nutr. 2009, 63 (Suppl. 2), S22-S33. [CrossRef] [PubMed]

15. Baer, D.J.; Judd, J.T.; Clevidence, B.A.; Tracy, R.P. Dietary fatty acids affect plasma markers of inflammation in healthy men fed controlled diets: A randomized crossover study. Am. J. Clin. Nutr. 2004, 79, 969-973. [CrossRef] [PubMed]

16. Lopez-Garcia, E.; Schulze, M.B.; Meigs, J.B.; Manson, J.E.; Rifai, N.; Stampfer, M.J.; Willett, W.C.; Hu, F.B. Consumption of trans fatty acids is related to plasma biomarkers of inflammation and endothelial dysfunction. J. Nutr. 2005, 135, 562-566. [CrossRef] [PubMed]

17. Iwata, N.G.; Pham, M.; Rizzo, N.O.; Cheng, A.M.; Maloney, E.; Kim, F. Trans fatty acids induce vascular inflammation and reduce vascular nitric oxide production in endothelial cells. PLoS ONE 2011, 6, e29600. [CrossRef]

18. Bryk, D.; Zapolska-Downar, D.; Malecki, M.; Hajdukiewicz, K.; Sitkiewicz, D. Trans fatty acids induce a proinflammatory response in endothelial cells through ROS-dependent nuclear factor-kappaB activation. J. Physiol. Pharmacol. 2011, 62, 229-238.

19. Pan, Y.; Liu, B.; Deng, Z.; Fan, Y.; Li, J.; Li, H. Lipid rafts promote trans fatty acid-induced inflammation in human umbilical vein endothelial cells. Lipids 2017, 52, 27-35. [CrossRef]

20. Da Silva, M.S.; Bilodeau, J.F.; Larose, J.; Greffard, K.; Julien, P.; Barbier, O.; Rudkowska, I. Modulation of the biomarkers of inflammation and oxidative stress by ruminant trans fatty acids and dairy proteins in vascular endothelial cells (HUVEC). Prostaglandins Leukot. Essent. Fatty Acids 2017, 126, 64-71. [CrossRef]

21. Da Silva, M.S.; Julien, P.; Bilodeau, J.F.; Barbier, O.; Rudkowska, I. Trans fatty acids suppress tnf-alpha-induced inflammatory gene expression in endothelial (HUVEC) and hepatocellular carcinoma (HepG2) cells. Lipids 2017, 52, 315-325. [CrossRef]

22. Soto-Vaca, A.; Losso, J.N.; McDonough, K.; Finley, J.W. Differential effect of 14 free fatty acids in the expression of inflammation markers on human arterial coronary cells. J. Agric. Food Chem. 2013, 61, 10074-10079. [CrossRef] [PubMed]

23. Baker, E.J.; Yusof, M.H.; Yaqoob, P.; Miles, E.A.; Calder, P.C. Omega-3 fatty acids and leukocyte-endothelium adhesion: Novel anti-atherosclerotic actions. Mol. Asp. Med. 2018, 64, 169-181. [CrossRef] [PubMed]

24. Lichtenstein, A.H. Dietary trans fatty acids and cardiovascular disease risk: Past and present. Curr. Atheroscler. Rep. 2014, 16, 433. [CrossRef]

25. Han, S.N.; Leka, L.S.; Lichtenstein, A.H.; Ausman, L.M.; Schaefer, E.J.; Meydani, S.N. Effect of hydrogenated and saturated, relative to polyunsaturated, fat on immune and inflammatory responses of adults with moderate hypercholesterolemia. J. Lipid Res. 2002, 43, 445-452. [CrossRef]

26. Smit, L.A.; Katan, M.B.; Wanders, A.J.; Basu, S.; Brouwer, I.A. A high intake of trans fatty acids has little effect on markers of inflammation and oxidative stress in humans. J. Nutr. 2011, 141, 1673-1678. [CrossRef] [PubMed]

27. Morris, M.C.; Evans, D.A.; Tangney, C.C.; Bienias, J.L.; Schneider, J.A.; Wilson, R.S.; Scherr, P.A. Dietary copper and high saturated and trans fat intakes associated with cognitive decline. Arch. Neurol. 2006, 63, 1085-1088. [CrossRef] [PubMed]

28. Wang, S.; Tian, W.; Liu, Y.; Yan, G.; Fang, S.; Wang, Y.; Yu, B. Temporal trend of circulating trans-fatty acids and risk of long-term mortality in general population. Clin. Nutr. 2021, 40, 1095-1101. [CrossRef]

29. Ruth, M.R.; Wang, Y.; Yu, H.M.; Goruk, S.; Reaney, M.J.; Proctor, S.D.; Vine, D.F.; Field, C.J. Vaccenic and elaidic acid modify plasma and splenocyte membrane phospholipids and mitogen-stimulated cytokine production in obese insulin resistant JCR: LA-cp rats. Nutrients 2010, 2, 181. [CrossRef]

30. Longhi, R.; Almeida, R.F.; Machado, L.; Duarte, M.M.; Souza, D.G.; Machado, P.; de Assis, A.M.; Quincozes-Santos, A.; Souza, D.O. Effect of a trans fatty acid-enriched diet on biochemical and inflammatory parameters in Wistar rats. Eur. J. Nutr. 2017, 56, 1003-1016. [CrossRef]

31. Martynowicz, H.; Janus, A.; Nowacki, D.; Mazur, G. The role of chemokines in hypertension. Adv. Clin. Exp. Med. 2014, 23, 319-325. [CrossRef]

32. Frank, P.G.; Lisanti, M.P. ICAM-1: Role in inflammation and in the regulation of vascular permeability. Am. J. Physiol. Heart Circ. Physiol. 2008, 295, H926-H927. [CrossRef] [PubMed]

33. Wang, Y.; Jacome-Sosa, M.M.; Ruth, M.R.; Goruk, S.D.; Reaney, M.J.; Glimm, D.R.; Wright, D.C.; Vine, D.F.; Field, C.J.; Proctor, S.D. Trans-11 vaccenic acid reduces hepatic lipogenesis and chylomicron secretion in JCR:LA-cp rats. J. Nutr. 2009, 139, $2049-2054$. [CrossRef] [PubMed]

34. Wang, Y.; Lu, J.; Ruth, M.R.; Goruk, S.D.; Reaney, M.J.; Glimm, D.R.; Vine, D.F.; Field, C.J.; Proctor, S.D. Trans-11 vaccenic acid dietary supplementation induces hypolipidemic effects in JCR:LA-cp rats. J. Nutr. 2008, 138, 2117-2122. [CrossRef] [PubMed]

35. Tyburczy, C.; Major, C.; Lock, A.L.; Destaillats, F.; Lawrence, P.; Brenna, J.T.; Salter, A.M.; Bauman, D.E. Individual trans octadecenoic acids and partially hydrogenated vegetable oil differentially affect hepatic lipid and lipoprotein metabolism in golden Syrian hamsters. J. Nutr. 2009, 139, 257-263. [CrossRef] [PubMed]

36. Blewett, H.J.; Gerdung, C.A.; Ruth, M.R.; Proctor, S.D.; Field, C.J. Vaccenic acid favourably alters immune function in obese JCR:LA-cp rats. Br. J. Nutr. 2009, 102, 526-536. [CrossRef]

37. Da Silva, M.S.; Julien, P.; Perusse, L.; Vohl, M.C.; Rudkowska, I. Natural rumen-derived trans fatty acids are associated with metabolic markers of cardiac health. Lipids 2015, 50, 873-882. [CrossRef] [PubMed]

38. Gebauer, S.K.; Destaillats, F.; Dionisi, F.; Krauss, R.M.; Baer, D.J. Vaccenic acid and trans fatty acid isomers from partially hydrogenated oil both adversely affect LDL cholesterol: A double-blind, randomized controlled trial. Am. J. Clin. Nutr. 2015, 102, 1339-1346. [CrossRef] [PubMed] 
39. Jaudszus, A.; Jahreis, G.; Schlormann, W.; Fischer, J.; Kramer, R.; Degen, C.; Rohrer, C.; Roth, A.; Gabriel, H.; Barz, D.; et al. Vaccenic acid-mediated reduction in cytokine production is independent of $c 9, t 11-C L A$ in human peripheral blood mononuclear cells. Biochim. Biophys. Acta 2012, 1821, 1316-1322. [CrossRef]

40. Krogager, T.P.; Nielsen, L.V.; Kahveci, D.; Dyrlund, T.F.; Scavenius, C.; Sanggaard, K.W.; Enghild, J.J. Hepatocytes respond differently to major dietary trans fatty acid isomers, elaidic acid and trans-vaccenic acid. Proteome Sci. 2015, 13, 31. [CrossRef] [PubMed]

41. Hu, S.B.; Zou, Q.; Lv, X.; Zhou, R.L.; Niu, X.; Weng, C.; Chen, F.; Fan, Y.W.; Deng, Z.Y.; Li, J. 9t18:1 and 11t18:1 activate the MAPK pathway to regulate the expression of PLA2 and cause inflammation in HUVECs. Food Funct. 2020, 11, 649-661. [CrossRef]

42. Akira, S.; Uematsu, S.; Takeuchi, O. Pathogen recognition and innate immunity. Cell 2006, 124, 783-801. [CrossRef] [PubMed]

43. Qiu, B.; Hu, J.N.; Liu, R.; Fan, Y.W.; Li, J.; Li, Y.; Deng, Z.Y. Caspase pathway of elaidic acid (9t-C18:1)-induced apoptosis in human umbilical vein endothelial cells. Cell Biol. Int. 2012, 36, 255-260. [CrossRef] [PubMed]

44. Abdelmagid, S.A.; Clarke, S.E.; Nielsen, D.E.; Badawi, A.; El-Sohemy, A.; Mutch, D.M.; Ma, D.W. Comprehensive profiling of plasma fatty acid concentrations in young healthy Canadian adults. PLoS ONE 2015, 10, e0116195. [CrossRef] [PubMed]

45. Fisk, H.L.; West, A.L.; Childs, C.E.; Burdge, G.C.; Calder, P.C. The use of gas chromatography to analyze compositional changes of fatty acids in rat liver tissue during pregnancy. J. Vis. Exp. JoVE 2014, 2014, e51445. [CrossRef] 